\title{
Using Hemoglobin A1c to Derive Mean Blood Glucose in Peritoneal Dialysis Patients
}

\author{
Junichi Hoshino a, b, h Rajnish Mehrotra ${ }^{c}$ Connie M. Rhee ${ }^{a, d}$ Kunihiro Yamagata \\ Yoshifumi Ubara $^{\text {h }}$ Kenmei Takaichi ${ }^{h}$ Csaba P. Kovesdy ${ }^{\text {e, }}$ Miklos Z. Molnar $^{a, j, k}$ \\ Kamyar Kalantar-Zadeh ${ }^{\mathrm{a}, \mathrm{g}}$ \\ ${ }^{a}$ Harold Simmons Center for Chronic Disease Research and Epidemiology, Los Angeles Biomedical Research Institute \\ at Harbor-UCLA Medical Center, Torrance, Calif., ${ }^{b}$ Department of Epidemiology, UCLA School of Public Health, \\ Los Angeles, Calif., 'Division of Nephrology, Harborview Medical Center, University of Washington, Seattle, Wash.,

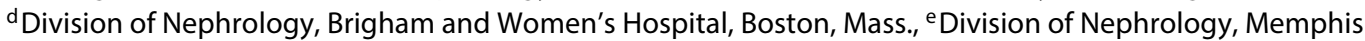 \\ Veterans Affairs Medical Center, Memphis Tenn., ${ }^{f}$ University of Tennessee Health Science Center, Memphis, Tenn., \\ and ${ }^{9}$ Division of Nephrology and Hypertension, University of California Irvine Medical Center, Orange, Calif., USA; \\ ${ }^{h}$ Nephrology Center, Toranomon Hospital, Tokyo, and 'Department of Nephrology, Faculty of Medicine, University of \\ Tsukuba, Tsukuba, Japan; ${ }^{j}$ Institute of Pathophysiology, Semmelweis University, Budapest, Hungary; ${ }^{k}$ Department of \\ Medicine, Division of Nephrology, University Health Network, University of Toronto, Toronto, Ont., Canada
}

\section{Key Words}

Hemoglobin A1c · Blood glucose $\cdot$ Equation model . Glycemic control · Albumin · Hemoglobin · Peritoneal dialysis · Race

\begin{abstract}
Background: Although hemoglobin A1c (HbA1c) has been widely used as a clinical assessment tool for outcome analyses related to glycemic control, the relationship between $\mathrm{HbA} 1 \mathrm{c}$ and average blood glucose (BG) specific to peritoneal dialysis (PD) patients with diabetes has not been characterized. We sought to develop HbA1c-BG equation models for PD patients. Methods: We examined associations between $\mathrm{HbA} 1 \mathrm{c}$ and random serum $\mathrm{BG}$ values over time in a contemporary 5-year (2001-2006) cohort of DaVita PD patients with diabetes. We identified 850 patients (mean age: $58 \pm 13$ years, $56 \%$ male) with 4,566 paired measurements of $\mathrm{HbA} 1 \mathrm{c}$ and $\mathrm{BG}$. The bootstrapping method was
\end{abstract}

used to estimate average BG and corresponding $\mathrm{HbA} 1 \mathrm{c}$. Results: Linear regression analyses yielded the following HbA1c-BG equations: (1) BG (mg/dl) $=24.1+28.6 \times \mathrm{HbA} 1 \mathrm{c}-$ $12.2 \times$ albumin [adjusted $R^{2}\left(R^{2}\right.$ adj $\left.=0.454\right)$ ], (2) $B G=55.3+$ $28.8 \times \mathrm{HbA} 1 \mathrm{c}-10.2 \times$ albumin $-3.3 \times \mathrm{Hb}\left(\mathrm{R}^{2}\right.$ adj $\left.=0.457\right)$, and (3) $\mathrm{BG}=69.5+28.7 \times \mathrm{HbA} 1 \mathrm{c}-10.1 \times$ albumin $-3.7 \times$ $\mathrm{Hb}-0.1 \times$ age + race/ethnicity (-10.1 African Americans, -5.4 other race/ethnicities; $\mathrm{R}^{2}$ adj $\left.=0.457\right)$. All models showed greater explanatory power of $B G$ variation than previously established $\mathrm{HbA} 1 \mathrm{c}-\mathrm{BG}$ equation models defined within non-PD cohorts $\left[\mathrm{R}^{2}\right.$ adj $=0.446$ for both the Diabetes Control and Complications Trial (DCCT) and the A1c-Derived Average Glucose (ADAG) equations]. Conclusions: The association between $\mathrm{HbA} 1 \mathrm{c}$ and $\mathrm{BG}$ in PD patients is different than that of patients with normal kidney function. Our analysis suggests that equations incorporating serum albumin and/or $\mathrm{Hb}$ values better estimate the $\mathrm{HbA} 1 \mathrm{c}-\mathrm{BG}$ relationship in $\mathrm{PD}$ patients compared to equations using HbA1c alone.
Copyright $\odot 2013$ S. Karger AG, Basel

\section{KARGER}

E-Mail karger@karger.com

www.karger.com/ajn (c) 2013 S. Karger AG, Basel

$0250-8095 / 13 / 0375-0413 \$ 38.00 / 0$
Kamyar Kalantar-Zadeh, MD, MPH, PhD

Harold Simmons Center for Kidney Disease Research and Epidemiology, Division of Nephrology and Hypertension, University of California Irvine (UCI) School of Medicine 101 The City Drive South, City Tower, Suite 400, ZOT: 4088 Orange, CA 92868-3217 (USA) E-Mail kkz@uci.edu 


\section{Introduction}

Hemoglobin A1c (HbA1c) is a clinically important assessment tool for evaluating the association between glycemic control and outcomes in diabetic patients. Two widely used equations for converting $\mathrm{HbAlc}$ into mean blood glucose (BG) levels have included the one derived from the Diabetes Control and Complications Trial [DCCT; average glucose $(\mathrm{mg} / \mathrm{dl})=35.6 \times \mathrm{HbAlc}-77.3$ ] and the A1c-Derived Average Glucose (ADAG) study formula [average glucose $(\mathrm{mg} / \mathrm{dl})=28.7 \times \mathrm{HbAlc}-46.7$ ], which were defined in populations without underlying kidney disease $[1,2]$. The ADAG group concluded that $\mathrm{HbA1c}$ is a reliable substitute for average BG and that aside from analytic variation, the only important determinant of the HbAlc is the preceding 3-month average glucose concentration.

The rate of $\mathrm{Hb}$ glycation is determined by temperature, serum $\mathrm{pH}, \mathrm{Hb}$ concentration, BG concentration, and length of exposure to glucose [3]. Given that dialysis patients have significantly altered $\mathrm{Hb}$ concentrations and $\mathrm{pH}$ levels, the correlation between $\mathrm{HbA1c}$ and BG levels in dialysis patients is different than that of patients with normal renal function. Furthermore, shortened erythrocyte life span and accelerated erythropoesis due to erythropoiesis-stimulating agent use may further alter $\mathrm{HbAlc}$ levels in dialysis patients. Indeed, $\mathrm{HbAlc}$ was found to underestimate glucose measurements compared to glycated albu$\mathrm{min}$ in diabetic patients on dialysis [4-6]. However, HbAlc is still a widely used measure of chronic glycemic control in dialysis patients [3]. Despite the increasing number of diabetic patients on dialysis and the fact that serum albumin levels are lower in patients undergoing peritoneal dialysis (PD) [7], an HbA1c-BG equation formula specific to this population has not yet been derived. Furthermore, the association between $\mathrm{HbAlc}$ and $\mathrm{BG}$ in $\mathrm{PD}$ patients may be different from hemodialysis (HD) patients, given that the former group is exposed to higher dialysate glucose concentrations. In this study, we sought to develop HbAlcBG equation models specific for PD patients.

\section{Subjects and Methods}

\section{Study Population}

The data were obtained from DaVita Inc., the second largest dialysis care provider in the United States with approximately 500 outpatient dialysis centers and 40,000 patients across the country. The creation of this national dialysis patient cohort has been described previously [8-13]. A 60-month prevalent cohort (July 2001 through June 2006) of patients undergoing PD patients was studied. Demo- graphic data and details of medical history were collected, with information on age, sex, race, and presence of diabetes. The study conformed to the Declaration of Helsinki and International Conference on Harmonization of Good Clinical Practice Guidelines.

Patients receiving dialysis for less than 90 days; those without diabetes; with missing values of albumin, glucose, $\mathrm{Hb}$, or $\mathrm{HbAlc}$; and with $<3$ measurements for each of these laboratory measures were excluded from this analysis. We divided race/ethnicity into four groups: non-Hispanic white, African American, Hispanic, and other. Asian Americans were included in the other race/ethnicity category due to low sample size.

\section{Laboratory Measures}

Blood samples were drawn using uniform techniques in all of the dialysis facilities and were transported to a central laboratory in Deland, Florida, typically within $24 \mathrm{~h}$. All laboratory values were measured by automated and standardized methods. Most laboratory values were measured monthly, including serum urea nitrogen, creatinine, albumin, BG, calcium, phosphate, and bicarbonate. HbAlc was measured at least quarterly and provided in National Glycohemoglobin Standardization Program units (\%).

Laboratory values in this dataset were refined using limits as follows: albumin, 1.0-5.0 g/dl; BG, 30-500 mg/dl; Hb, 3-20 g/dl; and $\mathrm{HbA} 1 \mathrm{c} 1-12 \%$. All repeated measures of every relevant variable for each patient within each calendar quarter of 13 weeks were averaged to obtain one quarterly mean value for that given variable.

\section{Statistical Methods}

Data were summarized using proportions, means $( \pm S D)$ as appropriate. Categorical variables were analyzed with the $\chi^{2}$ test or Fisher's exact test, and continuous variables were compared using a t test, Mann-Whitney $\mathrm{U}$ test, Kruskal-Wallis $\mathrm{H}$ test, or ANOVA, as appropriate. Averaged HbAlc values and BG values were compared using regression models with and without adjustment for $\mathrm{Hb}$, serum albumin, patients' age, sex, and/or race/ethnicity. For the creation of the equation, we averaged all the BG including the intervening months' $\mathrm{HbAlc}$ levels used in order to calculate individual patients' mean values. In addition to linear models, quadratic, root, log, and exponential regression models were also applied to estimate the relationship between averaged $\mathrm{HbA1c}$ and BG values. The bootstrapping method was also used to estimate average BG and corresponding $\mathrm{HbAlc}$ for more reliable estimates. The 1,000 resampling procedure with replacement was selected to approximate the sampling distribution of statistics of interest. Adjusted $\mathrm{R}^{2}\left(\mathrm{R}_{\text {adj }}^{2}\right)$ and root mean square error were used to compare the correlations between the simple and multivariate regression models. After identifying the best models, we applied them to sex- and race/ethnicity-based categories to compare the accuracy of the models in each subgroup. The DCCT and the ADAG equations were used as control estimates. All statistical analyses were carried out with SAS, version 9.3 (SAS Institute, Cary, N.C., USA).

\section{Results}

\section{Equation Model Creation}

We identified $850 \mathrm{PD}$ patients with 4,566 paired measurements of $\mathrm{HbA1c}$ and BG over a 5-year period. 
Table 1. Baseline patients' characteristics $(n=850)$

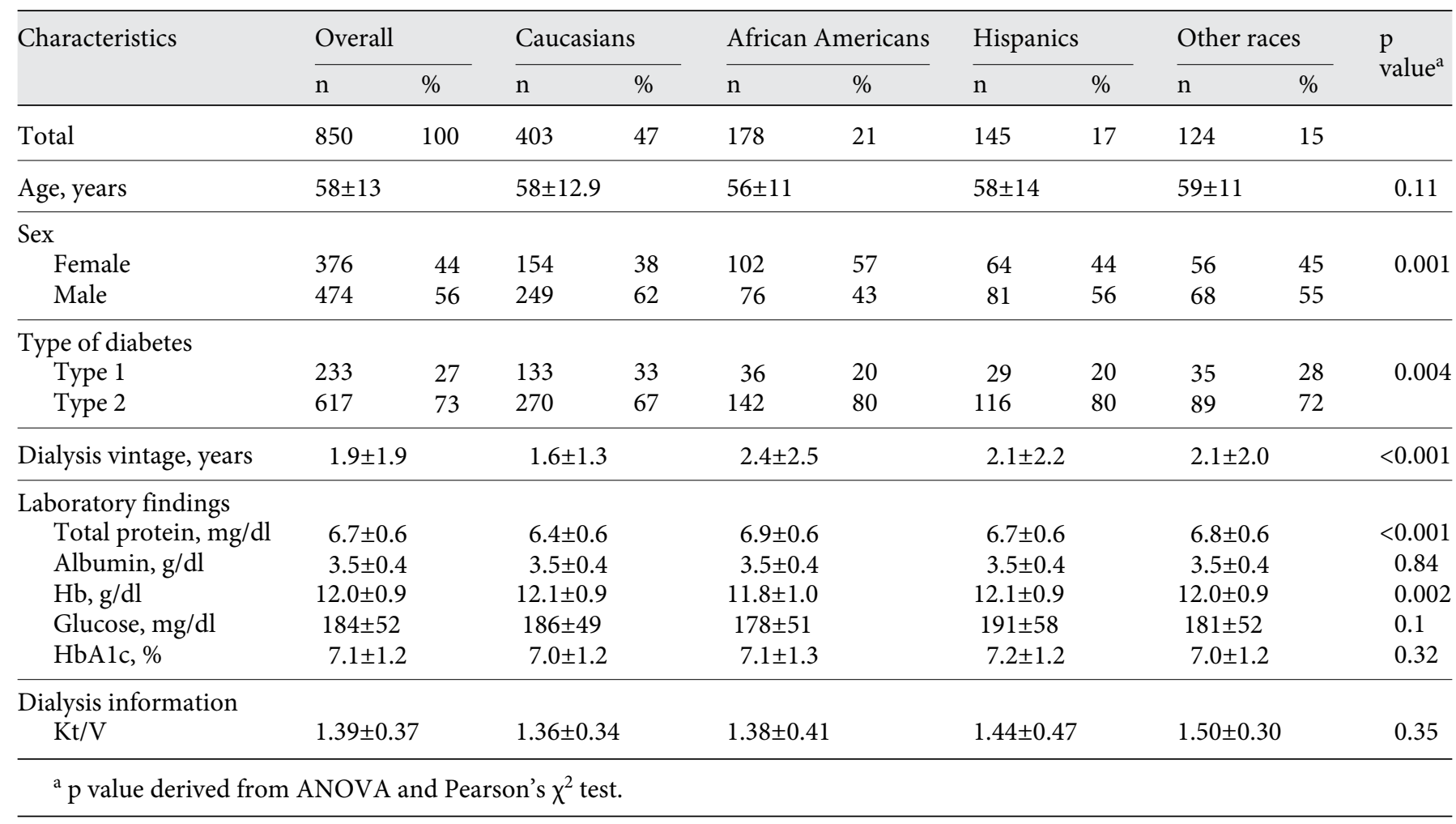

Baseline characteristics are shown in table 1. The overall cohort mean age was $58 \pm 13$ years, which was relatively lower in African Americans (56 \pm 11 years). The cohort was largely comprised of non-Hispanic whites (47\%), African Americans (21\%), and Hispanics (17\%), with relatively lower contributions from other race/ethnicities such as Asians, Pacific Islanders, and Native Americans. The mean dialysis vintage was $1.9 \pm 1.9$ years. Seventy-three percent of patients had type 2 diabetes mellitus.

The relationship between the average $\mathrm{HbAlc}$ and the average $B G$ is shown in figure 1 and table 2 . The scatter plot suggests that there is a linear relationship between $\mathrm{HbAlc}$ and BG, similar to the relationship previously reported in nondialysis populations $[1,2]$. Next, we compared several equation models with and without adjustment for confounding factors. As shown in table 2, the equation improved when serum albumin was added to the model $\left(\mathrm{R}_{\text {adj: }}^{2}\right.$ 0.446-0.453). The $\mathrm{R}_{\text {adj }}^{2}$ further increased after adding $\mathrm{Hb}$, age, and/or race/ethnicity variables, although the degree of improvement was not large. We did not observe an increase in the $\mathrm{R}^{2}$ adj after adding sex as a covariate, nor with employing quadratic, root, log, and exponential mod-

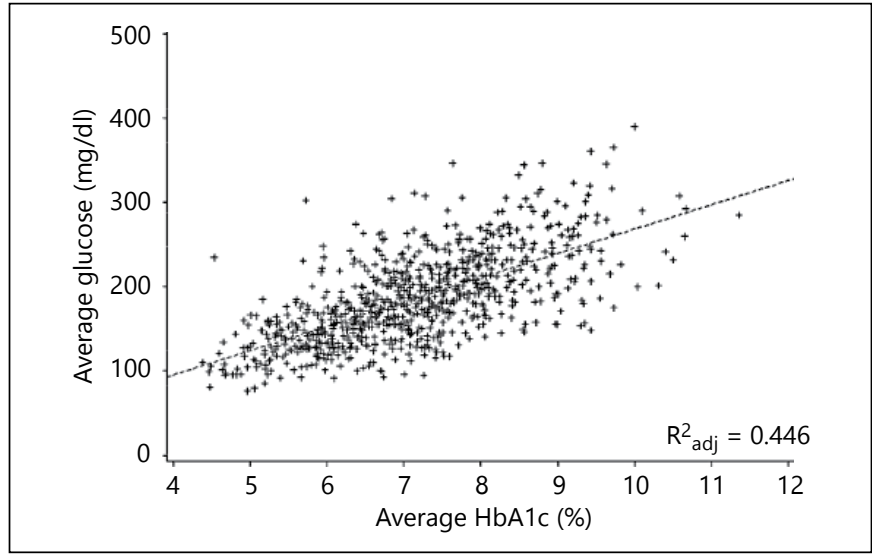

Fig. 1. Comparison between average $\mathrm{HbAlc}$ and average BG levels in each patient $(n=850)$. The $R^{2}$ adj for the fitted line was 0.446 .

els. For convenience of use in the clinical setting, we selected model 3 (equation incrementally adjusted for serum albumin) and model 4 (equation incrementally adjusted for serum albumin and $\mathrm{Hb}$ ) as the 'simple' models, and model 8 (fully adjusted model) as the 'complex' model. 
Table 2. Relationships between the average BG and the average HbAlc

\begin{tabular}{|c|c|c|c|c|c|}
\hline Model & Covariates & \multicolumn{2}{|l|}{ Mean $^{\mathrm{a}}$} & \multicolumn{2}{|c|}{ Bootstrapping } \\
\hline 2 & $\mathrm{AG}=30.7+29.1 \times \mathrm{HbAlc}-4.3 \times \mathrm{Hb}$ & 0.451 & 38.166 & 0.451 & 38.169 \\
\hline 3 & $\mathrm{AG}=24.1+28.6 \times \mathrm{HbA} 1 \mathrm{c}-12.2 \times \mathrm{Alb}$ & 0.453 & 38.102 & 0.453 & 38.097 \\
\hline 5 & $\mathrm{AG}=32.6+28.5 \times \mathrm{HbA} 1 \mathrm{c}-12.5 \times \mathrm{Alb}-0.1 \times$ age & 0.453 & 38.101 & 0.453 & 38.095 \\
\hline 6 & $\mathrm{AG}=33.4+28.5 \times \mathrm{HbA} 1 \mathrm{c}-13.4 \times \mathrm{Alb}-0.1 \times$ age $+4.2 \times$ sex & 0.454 & 38.068 & 0.454 & 38.061 \\
\hline 7 & $\mathrm{AG}=36.5+28.4 \times \mathrm{HbAlc}-12.4 \times \mathrm{Alb}-0.1 \times$ age + race $(-9.1$ if $\mathrm{AA},-4.6$ if others $)$ & 0.456 & 37.991 & 0.456 & 37.988 \\
\hline 10 & $\begin{array}{l}\mathrm{AG}=50.0+34.5 \times \mathrm{HbA} 1 \mathrm{c}-0.4 \times(\mathrm{HbAlc})^{2}-10.1 \times \mathrm{Alb}-3.8 \times \mathrm{Hb}-0.1 \times \text { age }+ \text { race } \\
(-10.0 \text { if } \mathrm{AA},-5.4 \text { if others })\end{array}$ & 0.460 & 37.864 & 0.460 & 37.877 \\
\hline
\end{tabular}

AG = Estimated average glucose; Alb: serum albumin; AA = African Americans; others: other races; RMSE = root mean square error. ${ }^{a}$ The mean BG and mean HbAlc were used to estimate correlations. ${ }^{b}$ The bootstrapping method was used to estimate the average $\mathrm{BG}$ and average $\mathrm{HbA1c}$.

\section{BG Estimation}

Next, we compared the average BG and estimated BG using our models and previously reported equations (ADAG and DCCT models established for nondialysis populations). Compared to these previously established equations ( $\mathrm{R}_{\text {adj: }}^{2} 0.446$ for both ADAG and DCCT models), our simple and complex models showed stronger correlations $\left(\mathrm{R}_{\text {adj: }}^{2} 0.454,0.457\right.$, and 0.457 for models 3 , 4 , and 8, respectively; fig. 2) in PD patients. In addition, the average BG levels estimated by the DCCT and ADAG models were similar to those estimated by our models if patients had serum albumin levels of $4.0 \mathrm{mg} / \mathrm{dl}$ and HbAlc levels $\geq 9.0 \%$. However, the estimated glucose levels by the previous models were lower if patients had serum albumin levels $<4.0 \mathrm{mg} / \mathrm{dl}$ or HbAlc levels $<9.0 \%$ (table 3).

\section{Utility of the Model in Race/Ethnicity-Based Subgroups}

Since the number of individuals in each race/ethnicity group was relatively small, it was essential to check the utility of the equation in each race/ethnicity group. As shown in table 4 , the $\mathrm{R}_{\text {adj }}{ }^{2}$ values between the average
BG and estimated BG using models 3 and 4 in nonHispanic whites were 0.414 and 0.419 , respectively. There were higher correlations in African Americans ( $\mathrm{R}_{\text {adj: }}^{2} 0.474$ and 0.473 for models 3 and 4 , respectively) and Hispanics ( $\mathrm{R}_{\text {adj: }}^{2} 0.556$ and 0.559 for models 3 and 4 , respectively) compared to non-Hispanic whites. These data suggested that this model may have particularly greater explanatory power of BG variation in African-American and Hispanic PD populations compared to their non-Hispanic white counterparts.

\section{Discussion}

In this relatively large-scale cohort of 850 diabetic PD patients with frequent glucose measurements $(4,566$ BG samples), we defined new equations of the association between $\mathrm{HbA1c}$ and BG, which performed as well as or superior to previously established $\mathrm{HbAlc}-\mathrm{BG}$ equations. To our knowledge, these are the first HbAlcBG models specific for PD patients, whereas previous standard formulas were developed for nondialysis patients. Interestingly, the slope of the HbAlc variable in 

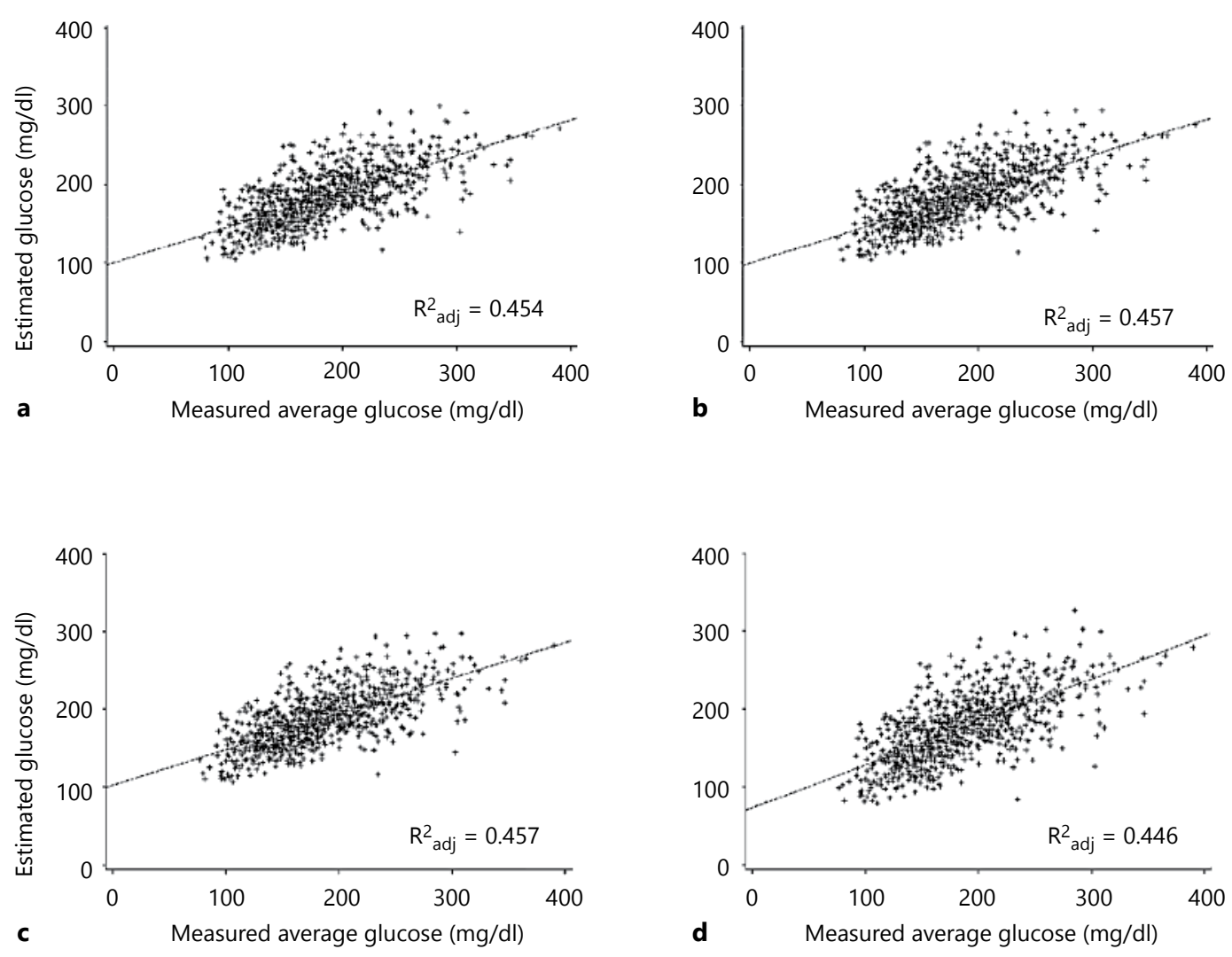

Fig. 2. Relationship between average $B G$ and estimated $B G$ according to different estimation models. a Model 3 (simple): estimated BG $(\mathrm{mg} / \mathrm{dl})=24.1+28.6 \times \mathrm{HbAlc}-12.2 \times \mathrm{Alb}\left(\mathrm{R}^{2}{ }_{\text {adj }}=\right.$ $0.454)$. b Model 4 (simple): estimated BG $(\mathrm{mg} / \mathrm{dl})=55.3+28.8 \times$ $\mathrm{HbA} 1 \mathrm{c}-10.2 \times \mathrm{Alb}-3.3 \times \mathrm{Hb}\left(\mathrm{R}_{\text {adj }}^{2}=0.457\right)$. c Model 8 (com-

our model was almost identical to that of the ADAG model. HbA1c has been observed to underestimate glucose measurements in diabetic PD and HD patients compared to glycated albumin [4-6, 14, 15]. Indeed, when we applied the ADAG and DCCT HbA1c-BG equations to our PD cohort, the estimated glucose levels calculated by these previous equations tended to be lower than the levels calculated by our equations (table 3).

Although a number of studies have shown that high and/or low HbA1c levels are associated with poorer outcomes in HD patients [16-20], there has been limited examination of the association between $\mathrm{HbAlc}$ and clinical outcomes in PD patients. To our knowledge, only two studies have examined the association between plex): $\mathrm{BG}(\mathrm{mg} / \mathrm{dl})=69.5+28.7 \times \mathrm{HbA1c}-10.1 \times \mathrm{Alb}-3.7 \times \mathrm{Hb}-$ $0.1 \times$ age + race/ethnicity ( -10.1 if African American, -5.4 if not Caucasian, Hispanic, or African American; $\left.\mathrm{R}_{\text {adi }}^{2}=0.457\right)$. $\mathrm{d}$ ADAG formula: $\mathrm{BG}(\mathrm{mg} / \mathrm{dl})=28.7 \times \mathrm{HbA1c}-46.7\left(\mathrm{R}_{\mathrm{adj}}^{2}=0.446\right)$. $\mathrm{Alb}=$ Serum albumin.
$\mathrm{HbA} 1 \mathrm{c}$ and clinical outcomes in PD patients to date [13, 21]. The issue of glycemic control may be particularly important for PD patients as PD solutions have high glucose concentrations, which may contribute to hyperglycemia in PD patients. Several other metrics of chronic glycemic levels in patients with chronic kidney disease have been identified, such as glycated albumin [22] and 1,5-anhydro-D-glucitol [23]. Nevertheless, HbAlc is still the most widely used glycemic control indicator for diabetic patients with and without kidney disease. A clear understanding of the relationship between $B G$ and $\mathrm{HbAlc}$ in dialysis patients is necessary for setting appropriate day-to-day BG goals according to specific $\mathrm{HbAlc}$ targets. Our model may be useful for interpreting and using $\mathrm{HbA} 1 \mathrm{c}$ as a reliable metric of glycemic control 
Table 3. Estimated glucose levels at each HbA1c and Alb levels in different models

\begin{tabular}{lllllll}
\hline \multirow{2}{*}{$\begin{array}{l}\text { HbA1c } \\
\%\end{array}$} & \multirow{2}{*}{$\begin{array}{l}\text { Alb } \\
\text { mg/dl }\end{array}$} & \multicolumn{5}{l}{ Estimated average glucose, mg/dl } \\
\cline { 3 - 7 } & & $\begin{array}{l}\text { model 3 } \\
\text { (+Alb) }\end{array}$ & $\begin{array}{l}\text { model } 4 \\
\text { (+Alb, Hb) }\end{array}$ & $\begin{array}{l}\text { model 8 } \\
\text { (complex) }\end{array}$ & $\begin{array}{l}\text { DCCT } \\
\text { model }\end{array}$ & $\begin{array}{l}\text { ADAG } \\
\text { model }\end{array}$ \\
\hline 5.0 & 4.0 & 118 & 126 & 127 & 101 & 97 \\
5.0 & 3.5 & 124 & 131 & 133 & & \\
5.0 & 3.0 & 131 & 136 & 138 & & \\
6.0 & 4.0 & 147 & 154 & 156 & 136 & 126 \\
6.0 & 3.5 & 153 & 159 & 161 & & \\
6.0 & 3.0 & 159 & 165 & 167 & & \\
7.0 & 4.0 & 176 & 183 & 185 & 172 & 154 \\
7.0 & 3.5 & 182 & 188 & 190 & & \\
7.0 & 3.0 & 188 & 193 & 195 & & \\
8.0 & 4.0 & 204 & 212 & 213 & 208 & 183 \\
8.0 & 3.5 & 210 & 217 & 219 & & \\
8.0 & 3.0 & 216 & 222 & 224 & & \\
9.0 & 4.0 & 233 & 241 & 242 & 243 & 212 \\
9.0 & 3.5 & 239 & 246 & 247 & & \\
9.0 & 3.0 & 245 & 251 & 253 & & \\
10.0 & 4.0 & 261 & 270 & 271 & 279 & 240 \\
10.0 & 3.5 & 267 & 275 & 276 & & \\
10.0 & 3.0 & 274 & 280 & 281 & & \\
\hline
\end{tabular}

All estimated glucose levels were for patients with $\mathrm{Hb} 10.0 \mathrm{~g} / \mathrm{dl}$ and 60 years of age. Note that all of these glucose levels are estimated values, not actual measured values. Alb $=$ Serum albumin. ${ }^{a}$ In model 8, all estimated glucose levels were for Caucasians (-10.0 if African American, -5.4 if other race).

Table 4. Correlation between estimated glucose and average glucose for patients on $\mathrm{PD}$

\begin{tabular}{|c|c|c|c|c|c|c|}
\hline \multirow[t]{2}{*}{ Race } & \multirow[t]{2}{*}{$\mathrm{n}$} & \multicolumn{5}{|l|}{$\mathrm{R}_{\text {adj }}^{2}$ value } \\
\hline & & $\begin{array}{l}\text { model } 3 \\
(\mathrm{~A} 1 \mathrm{c}+\mathrm{Alb})\end{array}$ & $\begin{array}{l}\text { model } 4 \\
(\mathrm{~A} 1 \mathrm{c}, \mathrm{Alb}, \mathrm{Hb})\end{array}$ & $\begin{array}{l}\text { model } 8 \\
\text { (complex) }\end{array}$ & DCCT & ADAG \\
\hline $\begin{array}{l}\text { Caucasians } \\
\text { African }\end{array}$ & 403 & 0.414 & 0.419 & 0.421 & 0.406 & 0.406 \\
\hline Americans & 178 & 0.474 & 0.473 & 0.472 & 0.468 & 0.468 \\
\hline Hispanics & 145 & 0.556 & 0.559 & 0.561 & 0.543 & 0.543 \\
\hline Other races & 124 & 0.421 & 0.434 & 0.428 & 0.422 & 0.422 \\
\hline Total & 850 & 0.454 & 0.457 & 0.457 & 0.446 & 0.446 \\
\hline
\end{tabular}

within the PD population despite confounding factors. With regard to equations for HD patients, we have recently reported three models for $\mathrm{HD}$ patients: $\mathrm{BG}=$ $59.2+29.4 \times \mathrm{HbAlc}-20.8 \times$ serum albumin $\left(\mathrm{R}^{2}=\right.$ $0.483), \mathrm{BG}=104.8+29.7 \times \mathrm{HbA1c}-18.4 \times$ serum albu- $\min -4.7 \times \mathrm{Hb}\left(\mathrm{R}^{2}=0.486\right)$, and $\mathrm{BG}=82.9+30.7 \times$ HbAlc $-16.5 \times$ serum albumin $-5.4 \times \mathrm{Hb}+0.3 \times$ age + race $\left(R^{2}=0.491\right)$ [24]. Compared to the equations for $P D$ patients, the coefficient of albumin was larger in HD patients. We could not fully explain why this discrepancy occurs; however, it might be possible that the constant $\mathrm{pH}$ environment in $\mathrm{PD}$ and continuous exposure of PD solutions with high glucose concentrations may contribute to this discrepancy.

In this study, we proposed three HbA1c-BG equations. We believe model 3 [BG $(\mathrm{mg} / \mathrm{dl})=24.1+28.6 \times$ HbAlc - $12.2 \times$ serum albumin)] may be the most straightforward and practical equation for daily use, given that PD patients have fairly uniform Hb levels as recommended by clinical guidelines, and given the significant interaction between anemia, serum albumin, and mortality predictability of $\mathrm{HbAlc}$ [13]. In addition, our analysis revealed that careful interpretation of $\mathrm{HbAlc}$ is needed in patients with protein-energy wasting and anemia since their HbAlc levels tend to be lower than the levels in dialysis patients [19]. In these patients, equation models which include serum albumin and $\mathrm{Hb}$ (model 4 or the complex model) may be useful in estimating their average glucose level. We previously reported that the $\mathrm{HbAlc}$ threshold for higher all-cause mortality was lower in Caucasians [13]. One of the reasons for this observation may be due to the differential association between $\mathrm{HbAlc}$ and BG across different race/ethnicities, which has been demonstrated in the general population [25]. Indeed, according to our equation model that was inclusive of race/ethnicity, the average BG is higher in Caucasians compared to African Americans with similar HbAlc levels. Although the difference in $\mathrm{R}^{2}$ between our models and the previous models was not large, compared to the distributions of estimated BG and actual BG in these models, our models showed better associations than the previous models, especially in a usual BG range such as BG of 100-250 mg/dl (fig. 2).

This study has several limitations. First, our data was not based on continuous daily BG monitoring. Although the association between mean BG obtained by continuous glucose monitoring and self-monitoring $B G$ were reported [15], the association between mean BG obtained by continuous glucose monitoring and multiple random BG has not been well established. However, the large number of random BG samples available to us and the bootstrapping technique may minimize this problem. Furthermore, our equations obtained by bootstrapping showed similar results to the estimation obtained by using time-averaged values, suggesting robustness of our 
models. Second, we did not have any data available on medications, PD modality (continuous ambulatory or automated PD), or dialysis prescription. However, the influences of these on our equation models are likely to be comparatively smaller. Third, our HbA1c-BG model might not be valid in certain racial/ethnic subgroups such as Asians due to the low prevalence in our cohort. Fourth, we did not look at the applicability of these equations in nondialysis patients with and without chronic kidney disease. Finally, our population consisted of patients with relatively shorter dialysis vintage. The association between $\mathrm{HbAlc}$ and glucose may be different in patients with longer vintage because uremia, nutritional status, and routine use of erythropoietin influence HbA1c levels.

In conclusion, there was a predictable relationship between $\mathrm{HbA} 1 \mathrm{c}$ and BG in PD patients. Our new models for $\mathrm{PD}$ patients showed stronger correlations between $\mathrm{HbAlc}$ and BG compared to previous models. The model inclusive of serum albumin may be better suited for PD patients because of the systematically lower serum albumin levels in this patient population [7]. By providing more reliable estimation of ambient blood glucose levels, our
HbA1c-BG models may allow health care providers and PD patients to better target and achieve optimal glycemic control.

\section{Acknowledgement}

We thank DaVita Clinical Research for providing the clinical data and review for this research project. The study was supported by K.K.-Z.'s research grants from the National Institute of Diabetes, Digestive and Kidney Disease of the National Institute of Health (R01 DK078106); a research grant from DaVita Clinical Research; and a philanthropic grant from Mr. Harold Simmons. M.Z.M. is recipient of the Hungarian Eötvös Scholarship (MÖB/77-2/2012). C.M.R. is supported by an NIH/NIDDK grant (F32 DK093201). R.M. and K.K.-Z. are supported by research grant RO1 DK95668.

\section{Disclosure Statement}

Dr. Kalantar-Zadeh is the medical director of DaVita HarborUCLA/MFI in Long Beach, Calif., USA. Dr. Mehrotra has received grant support and/or honoraria from Baxter Healthcare and DaVita Inc. The other authors have not declared any conflict of interest.

\section{References}

$\checkmark 1$ Rohlfing CL, Wiedmeyer HM, Little RR, England JD, Tennill A, Goldstein DE: Defining the relationship between plasma glucose and $\mathrm{HbA}(1 \mathrm{c})$ : Analysis of glucose profiles and $\mathrm{HbA}(1 \mathrm{c})$ in the Diabetes Control and Complications Trial. Diabetes Care 2002;25:275-278.

2 Nathan DM, Kuenen J, Borg R, Zheng H, Schoenfeld D, Heine RJ, A1c-Derived Average Glucose Study Group: Translating the A1C assay into estimated average glucose values. Diabetes Care 2008;31:1473-1478.

3 Kovesdy CP, Park JC, Kalantar-Zadeh K: Glycemic control and burnt-out diabetes in ESRD. Semin Dial 2010;23:148-156.

4 Peacock TP, Shihabi ZK, Bleyer AJ, Dolbare EL, Byers JR, Knovich MA, Calles-Escandon J, Russell GB, Freedman BI: Comparison of glycated albumin and hemoglobin A(1c) levels in diabetic subjects on hemodialysis. Kidney Int 2008;73:1062-1068.

5 Nagayama H, Inaba M, Okabe R, Emoto M, Ishimura E, Okazaki S, Nishizawa Y: Glycated albumin as an improved indicator of glycemic control in hemodialysis patients with type 2 diabetes based on fasting plasma glucose and oral glucose tolerance test. Biomed Pharmacother 2009;63:236-240.

6 Uzu T, Hatta T, Deji N, Izumiya T, Ueda H, Miyazawa I, Kanasaki M, Isshiki K, Nishio T, Arimura T: Target for glycemic control in type 2 diabetic patients on hemodialysis: effects of anemia and erythropoietin injection on hemoglobin A(1c). Ther Apher Dial 2009; 13:89-94.

7 Mehrotra R, Duong U, Jiwakanon S, Kovesdy CP, Moran J, Kopple JD, Kalantar-Zadeh K: Serum albumin as a predictor of mortality in peritoneal dialysis: comparisons with hemodialysis. Am J Kidney Dis 2011;58:418-428.

-8 Kalantar-Zadeh K, Streja E, Kovesdy CP, Oreopoulos A, Noori N, Jing J, Nissenson AR, Krishnan M, Kopple JD, Mehrotra R, Anker SD: The obesity paradox and mortality associated with surrogates of body size and muscle mass in patients receiving hemodialysis. Mayo Clin Proc 2010;85:991-1001.

-9 Kalantar-Zadeh K, Shah A, Duong U, Hechter RC, Dukkipati R, Kovesdy CP: Kidney bone disease and mortality in CKD: revisiting the role of vitamin $\mathrm{D}$, calcimimetics, alkaline phosphatase, and minerals. Kidney Int Suppl 2010;117:S10-S21.

10 Miller JE, Kovesdy CP, Norris KC, Mehrotra R, Nissenson AR, Kopple JD, Kalantar-Zadeh $\mathrm{K}$ : Association of cumulatively low or high serum calcium levels with mortality in longterm hemodialysis patients. Am J Nephrol 2010;32:403-413.

-11 Miller JE, Kovesdy CP, Nissenson AR, Mehrotra R, Streja E, Van Wyck D, Greenland S,
Kalantar-Zadeh K: Association of hemodialysis treatment time and dose with mortality and the role of race and sex. Am J Kidney Dis 2010;55:100-112.

12 Molnar MZ, Huang E, Hoshino J, Krishnan M, Nissenson AR, Kovesdy CP, Kalantar-Zadeh K: Association of pretransplant glycemic control with posttransplant outcomes in diabetic kidney transplant recipients. Diabetes Care 2011;34:2536-2541.

13 Duong U, Mehrotra R, Molnar MZ, Noori N, Kovesdy CP, Nissenson AR, KalantarZadeh K: Glycemic control and survival in peritoneal dialysis patients with diabetes mellitus. Clin J Am Soc Nephrol 2011;6: 1041-1048.

14 Freedman BI, Shenoy RN, Planer JA, Clay KD, Shihabi ZK, Burkart JM, Cardona CY, Andries L, Peacock TP, Sabio H, Byers JR, Russell GB, Bleyer AJ: Comparison of glycated albumin and hemoglobin Alc concentrations in diabetic subjects on peritoneal and hemodialysis. Perit Dial Int 2010;30: 72-79.

-15 Vos FE, Schollum JB, Coulter CV, Manning PJ, Duffull SB, Walker RJ: Assessment of markers of glycaemic control in diabetic patients with chronic kidney disease using continuous glucose monitoring. Nephrology (Carlton) 2012;17:182-188. 
16 Kalantar-Zadeh K, Kopple JD, Regidor DL, Jing J, Shinaberger CS, Aronovitz J, McAllister CJ, Whellan D, Sharma K: Alc and survival in maintenance hemodialysis patients. Diabetes Care 2007;30:1049-1055.

17 Williams ME, Lacson E Jr, Wang W, Lazarus JM, Hakim R: Glycemic control and extended hemodialysis survival in patients with diabetes mellitus: comparative results of traditional and time-dependent Cox model analyses. Clin J Am Soc Nephrol 2010;5:1595-1601.

18 Ricks J, Molnar MZ, Kovesdy CP, Shah A, Nissenson AR, Williams M, Kalantar-Zadeh K: Glycemic control and cardiovascular mortality in hemodialysis patients with diabetes: a 6-year cohort study. Diabetes 2012;61:708-715.

19 Park J, Lertdumrongluk P, Molnar MZ, Kovesdy CP, Kalantar-Zadeh K: Glycemic control in diabetic dialysis patients and the burnt-out diabetes phenomenon. Curr Diab Rep 2012;12:432-439.

20 Williams ME, Lacson E Jr, Teng M, Hakim RM, Lazarus JM: Extremes of glycemic control (HbAlc) increase hospitalization risk in diabetic hemodialysis patients in the USA. Am J Nephrol 2009;29:54-61.

21 Wu MS, Yu CC, Wu CH, Haung JY, Leu ML, Huang CC: Pre-dialysis glycemic control is an independent predictor of mortality in type II diabetic patients on continuous ambulatory peritoneal dialysis. Perit Dial Int 1999; 19(Suppl 2):S179-S183.

22 Freedman BI, Andries L, Shihabi ZK, Rocco MV, Byers JR, Cardona CY, Pickard MA, Henderson DL, Sadler MV, Courchene LM, Jordan JR, Balderston SS, Graham AD, Mauck VL, Russell GB, Bleyer AJ: Glycated albumin and risk of death and hospitalizations in dia- betic dialysis patients. Clin J Am Soc Nephrol 2011;6:1635-1643.

23 Kim WJ, Park CY, Lee KB, Park SE, Rhee EJ, Lee WY, Oh KW, Park SW: Serum 1,5-anhydroglucitol concentrations are a reliable index of glycemic control in type 2 diabetes with mild or moderate renal dysfunction. Diabetes Care 2012;35:281-286.

24 Hoshino J, Molnar MZ, Yamagata K, Ubara Y, Takaichi K, Kovesdy CP, Kamyar K-Z: Developing an $\mathrm{HbAlc-based} \mathrm{equation} \mathrm{to} \mathrm{esti-}$ mate blood glucose in maintenance hemodialysis patients. Diabetes Care 2012, E-pub ahead of print.

25 Bleyer AJ, Hire D, Russell GB, Xu J, Divers J, Shihabi Z, Bowden DW, Freedman BI: Ethnic variation in the correlation between random serum glucose concentration and glycated haemoglobin. Diabet Med 2009;26:128-133. 